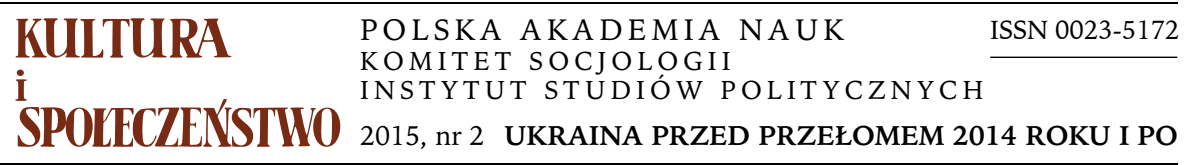

JOANNA KONIECZNA-SAEAMATIN

Uniwersytet Warszawski

\title{
PARTIA „TRUDNO POWIEDZIEĆ” NA UKRAINIE CO O UKRAIŃSKIM SPOŁECZEŃSTWIE MÓWI UCHYLANIE SIĘ OD ODPOWIEDZI W BADANIACH SONDAŻOWYCH
}

W ciągu ostatniego ćwierćwiecza ukraińskie społeczeństwo przeżyło wiele wstrząsów. Jednym z najistotniejszych było powstanie Ukrainy jako niepodległego państwa. O swoim państwie Ukraińcy, ukraińskie elity, mówili, pisali i marzyli, ale mało kto spodziewał się, że pod koniec XX wieku ta perspektywa jest tak realna. W tym kontekście przypomina mi się tytuł książki Andrew Wilsona (2002), który w angielskim oryginale brzmi The Ukrainians. Unexpected Nation, czyli „naród nieoczekiwany”. Dla zachodniego historyka ważne było odkrycie, że na wschód od Bugu jest nie tylko Rosja, ale coś jeszcze. Wydaje się jednak, że i dla samych Ukraińców fakt, że z mieszkańców ZSRR mają stać się narodem i obywatelami własnego państwa, również był w znacznym stopniu nieoczekiwany — byli do tego nieprzygotowani.

Zaskoczenie to ujawnia się w wynikach badań socjologicznych, w których Ukraińcy demonstrują zagubienie i niezdecydowanie. W sondażu prowadzonym w listopadzie 1991 roku, czyli miesiąc przed referendum zatwierdzającym Akt Niepodległości Ukrainy, aż jedna czwarta badanych (25\%) nie wiedziała, jaką podejmie decyzję (Chmelko 2014) ${ }^{1}$. Czy rzeczywiście nie wiedzieli, jak zagłosować, czy też raczej nie wiedzieli, co powinni odpowiadać ankieterom?

Analizę szczególnego zachowania się społeczeństwa ukraińskiego w badaniach sondażowych warto rozpocząć od uświadomienia sobie społecznego kontekstu badań socjologicznych w krajach byłego ZSRR. Mimo że od roz-

\section{Adres do korespondencji: jkonieczna@uw.edu.pl}

${ }^{1} \mathrm{~W}$ rezultacie, jak pamiętamy, ponad 90,3\% oddanych głosów padło za zatwierdzeniem niepodległości. 
wiązania tego państwa minęło już blisko dwadzieścia pięć lat, jego duch ciągle unosi się nad mieszkańcami dawnych republik związkowych i w sposób mniej lub bardziej przez nich uświadomiony wpływa na ich wybory i działania.

W ZSRR sondaży nie prowadzono ${ }^{2}$. Badań rynku gospodarka powszechnego niedoboru nie potrzebowała, a sondaże dotyczące spraw społecznych czy politycznych były w ogóle trudne do wyobrażenia. Przynajmniej do początków pierestrojki (czyli mniej więcej do 1985 roku) sama myśl o tym, że może istnieć jakaś „publiczna” opinia odbiegająca od oficjalnego stanowiska partii i rządu, mogła zostać potraktowana jako nielojalność w stosunku do tejże partii i surowo ukarana. Ze względu na to badania opinii publicznej po rozpadzie ZSRR miały posmak działalności niemal „dysydenckiej”, a publikacja ich wyników przyciągała znacznie większą uwagę i wywoływała więcej emocji niż w krajach $z$ długą tradycją demokratyczną.

Dziś na Ukrainie prowadzi się bardzo wiele badań społecznych i są to nie tylko przedwyborcze sondaże opinii publicznej. Od 1991 roku Ukraina bierze udział w międzynarodowych projektach badawczych, takich jak European Values Survey, World Values Suvey, European Social Survey i wiele innych. Właśnie te międzynarodowe badania pozwoliły zauważyć, że częstość wybierania przez Ukraińców odpowiedzi „trudno powiedzieć” lub różnych jej modyfikacji jest relatywnie wysoka $\mathrm{w}$ porównaniu $\mathrm{z}$ innymi krajami. Jest to różnica systematyczna, pojawiająca się $w$ badaniach o rozmaitej tematyce i stale utrzymująca się mimo upływu czasu oraz wydarzeń społecznych i politycznych angażujących — jak mogłoby się wydawać — znaczną część społeczeństwa ukraińskiego i zwracających jego uwagę na sprawy publiczne.

Zjawisko to było zauważane przez badaczy zajmujących się społeczeństwem Ukrainy (Riabchuk 1998; Chudowsky, Kuzio 2003), nie doczekało się jednak systematycznego opisu. Nie podejmowano też próby wyjaśnienia, skąd bierze się to szczególne przywiązanie Ukraińców do odpowiedzi „trudno powiedzieć” i czy oznacza ono rzeczywisty brak opinii występujący częściej niż w innych społeczeństwach, czy też niechęć do dzielenia się tą opinią z badaczami.

W opublikowanym kilka lat temu artykule (Konieczna-Sałamatin 2011) przyglądałam się bliżej innej grupie niezdecydowanych Ukraińców - tym, którzy nie wiedzą, jaki wybór geopolityczny, integracja z Rosją czy z Unią Europejską, byłby najlepszą opcją dla Ukrainy i wskazują jako pożądane jednocześnie obydwa kierunki integracji. Okazało się wtedy, że ci niezdecydowani, to właściwie odzwierciedlenie populacji, czyli tacy „przeciętni Ukraińcy”. Nie wyróżniali się ani cechami demograficznymi (np. płcią, wiekiem czy poziomem wykształcenia), ani nawet regionem zamieszkania, choć ta cecha zazwyczaj bardzo silnie różnicuje poglądy i zachowania polityczne Ukraińców.

2 O historii badań sondażowych w Rosji i ZSRR zob. Mansurow, Pietrienko 1996. 
Kontynuuję tutaj poszukiwanie przyczyn ujawniającego się w sondażach niezdecydowania Ukraińców. Tym razem przedmiotem analizy jest niechęć respondentów do wyrażania swoich opinii w różnych sprawach - nie tylko dotyczących polityki zagranicznej — i dzielenia się nimi z ankieterami zbierającymi dane dla potrzeb badań społecznych. Podejmuje próbę odpowiedzi na pytanie, czy rzeczywiście można mówić o „partii trudno powiedzieć” na Ukrainie i czy osoby uchylające się od odpowiedzi w badaniach sondażowych faktycznie nie mają opinii o badanych zagadnieniach, czy też te opinie ukrywają przed badaczami. Innymi słowy - czy „nie wiem” znaczy „nie wiem”, czy też może respondenci ci mówią coś jeszcze.

\section{DLACZEGO NIEKTÓRYM „TRUDNO POWIEDZIEĆ” I CO Z TEGO WYNIKA?}

Udzielanie odpowiedzi zwanych przez niektórych badaczy „beztreściowymi" było przedmiotem refleksji wielu socjologów. Najdalej chyba idącą interpretację tego typu reakcji na pytania ankietowe dotyczące kwestii politycznych pod koniec lat siedemdziesiątych XX wieku przedstawił Pierre Bourdieu (1984). Opierając się na konstatacji, że odpowiedzi typu „nie wiem” częściej padają $\mathrm{w}$ odpowiedzi na pytania dotyczące kwestii politycznych niż innych spraw, uznał, że jest to wyraz braku odpowiedniego kapitału kulturowego, który pozwalałby na adekwatne funkcjonowanie w polu politycznym. Wynika to, zdaniem Bourdieu, z tego, że dominujący wytwarzają dyskurs, w którym tylko oni potrafią się poruszać i tylko oni mają odpowiednie kompetencje, by się wypowiadać. Prowadzi to do relatywnego wykluczenia zdominowanych, którzy rzadziej zabierają głos w kwestiach politycznych, rzadziej też uczestniczą w wyborach, i w rezultacie istniejący porządek społeczny się reprodukuje. Na kształt systemu politycznego mają wpływ tylko ci, którzy ten system współtworzą (dominujący) i nie są zainteresowani jego zmianą.

Polscy badacze podjęli temat odpowiedzi „trudno powiedzieć” w końcu lat osiemdziesiątych, gdy zaobserwowali wzrost ich odsetka $\mathrm{w}$ powtarzanym cyklicznie w ciągu kilku lat badaniu pt. „Polacy” (Gęsicka i in. 1987; Śmiłowski 1987; Lutyńska 1990). Jedną z podnoszonych w tym kontekście kwestii, która jest istotna także dla problemu tu postawionego, było pytanie, o przyczyny udzielania odpowiedzi typu „nie wiem”.

Badacze zazwyczaj nie wierzą respondentom, że ci rzeczywiście nie wiedzą, co mają odpowiedzieć, i starają się poszukiwać interpretacji tych odpowiedzi jako zachowania „ucieczkowego”, którego celem jest uniknięcie odpowiedzi na zadane w sondażu pytanie. Przekonujące argumenty na rzecz tego, że odpowiedź „nie wiem” jest znacząca, przedstawił między innymi zespół George’a Bishopa (1996), zwracając uwagę na to, że odpowiedź ta jest dla respondenta bardziej psychologicznie kosztowna, zwłaszcza gdy nie jest bezpośrednio oferowana $\mathrm{w}$ kwestionariuszu. Badani są zazwyczaj zachęcani do udzielenia merytorycznej odpowiedzi, między innymi przez podpowiadanie im gotowych 
wariantów, spośród których należy tylko wybrać. Ponadto istnieje rodzaj społecznej presji na udzielanie odpowiedzi na pytania ankiety.

„Ucieczkowy” charakter odpowiedzi „trudno powiedzieć” udokumentowała między innymi przywołana już Krystyna Lutyńska w wielu pracach opartych na danych z polskich badań (zob. np. Lutyńska 1990). Wykazała ona, że najistotniejszymi czynnikami skłaniającymi respondenta do unikania odpowiedzi merytorycznych są trudność pytania i jego drażliwość, przy czym ta ostatnia ma większe znaczenie.

Trudność pytania była określana przez cztery wymiary: odbiór słuchowy pytania (w tym między innymi jego długość i złożoność gramatyczna), stopień skomplikowania „zadania”, jakie jest stawiane przed respondentem w pytaniu (np. wybrać trzy odpowiedzi z dziesięciu); trudność językową (np. słowa trudne, z języka specjalistycznego) i skomplikowanie oczekiwanej odpowiedzi (np. konieczność dokonywania obliczeń, przypominania sobie itp.).

Przez drażliwość pytania autorka rozumiała - za Włodzimierzem Rostockim (1974) - wywoływanie przez pytanie „niepożądanych procesów psychicznych związanych z różnymi emocjami (np. obawa, zaniepokojenie, zażenowanie itp.)". Drażliwość pytania jest, jak podkreślano, zawsze relatywna i związana z następującymi aspektami: sfera prywatności i intymności, poczucie społecznej wartości badanego i społeczna egzystencja badanego. Stopień drażliwości pytania może zależeć od czynników, których wystąpienie lub ich brak trudno jest stwierdzić post factum, analizując tylko dane $z$ badań - na przykład od atmosfery wywiadu, stosunku respondenta do badań lub też od odbioru przez respondenta ogólnej sytuacji w kraju.

Warto bliżej przyjrzeć się czynnikom określającym drażliwość pytań, gdyż — jak zobaczymy dalej - niektóre z nich mogą mieć bezpośrednie zastosowanie do pytań zadawanych $w$ analizowanych tu ukraińskich sondażach. Zgodnie z przedstawioną definicją, za drażliwe mogą zostać uznane pytania, które naruszają „sferę prywatności i intymności”. Do sfery tej należą jednak, zdaniem Lutyńskiej, nie tylko sprawy ściśle prywatne, ale również te $z$ różnych powodów stanowiące tabu. Na przykład w czasach komunistycznych, w których ta koncepcja została sformułowana, do tabu w społeczeństwie polskim należały opinie dotyczące spraw politycznych: stosunek do Związku Radzieckiego, do panującego ustroju, a także ocena niektórych wydarzeń czy faktów z historii, o których nie uczono w szkołach itp.

Krystyna Lutyńska pisze (1990, s. 29):

„Ponieważ w naszym kraju propaganda i w ogóle wychowanie człowieka od najmłodszych lat zmierzały do tego, aby ludzie myśleli i pewne sprawy oceniali w określony sposób, każdy właściwie temat poruszany publicznie, w zależności od aktualnej linii politycznej, mógł stać się «tabu», co rzutuje zwłaszcza na sytuację wywiadu, kiedy wymagamy od respondenta szczerości i otwartości. Zgodnie z koncepcją dwójmyślenia, badany albo musi się zdobyć na odwagę i przedstawić swoje własne "prywatne», intymne poglądy, albo też będzie wy- 
głaszał tylko opinie «oficjalne» i ewentualnie szukał ucieczki w «trudno powiedzieć»".

Cytuję ten fragment, gdyż przedstawiony w nim opis sytuacji społecznej Polski końca lat osiemdziesiątych można odnieść do Ukrainy i społeczeństwa ukraińskiego i w tym kontekście byłby chyba jeszcze bardziej trafny. Okres monopolu władzy na język publiczny i działania kontrolowanych przez państwo mediów trwał tam dłużej niż w Polsce, bo zaczął się znacznie przed rokiem 1945 i nie zakończył się tak jednoznacznie po upadku ZSRR. Ze względu na to długie funkcjonowanie w warunkach scentralizowanej propagandy i represji za „nieprawomyślność” Ukraińcy — podobnie jak inni mieszkańcy byłych republik związkowych - wypracowali umiejętność sprawnego przyswajania sobie „oficjalnego” punktu widzenia, którym mogli się posłużyć zawsze, gdy nie chcieli lub obawiali się ujawniać przed rozmówcą swoich rzeczywistych poglądów. Dodać należy również to, że Ukraińcy mieli znacznie mniej czasu niż Polacy na oswojenie się $\mathrm{z}$ badaniami sondażowymi ${ }^{3}$.

Wszystko to sprawia, że prawdopodobnie do dziś wielu ukraińskich respondentów nieadekwatnie interpretuje sytuację wywiadu socjologicznego, uważając ją za rodzaj kontroli, egzaminowania, ewentualnie zbieranie informacji do publikacji w gazecie. Ankieter jako osoba przychodząca ze świata zewnętrznego i obca jest więc niekoniecznie $\mathrm{w}$ takim stopniu godny zaufania, by dzielić się z nim „prywatnymi” poglądami. Respondenci wygłaszają więc w takiej sytuacji opinie „oficjalne”, a raczej takie, które za oficjalne uważają. Warto w tym kontekście zwrócić uwagę na to, że w miarę rozwoju demokracji i pluralizmu na Ukrainie coraz częściej zdarza się, że nie zawsze i nie w każdej sprawie wiadomo, jaki ten „oficjalny” punkt widzenia jest. Wówczas pozostaje już tylko skorzystać z opcji „trudno powiedzieć” albo zaufać ankieterowi.

\section{WYKORZYSTANE DANE}

Empiryczną bazą dla zaprezentowanych tu analiz jest międzynarodowy projekt badawczy European Values Survey z lat 1999 i 2008 oraz badania sondażowe prowadzone przez Centrum Razumkowa wspólnie z Fundacją „Inicjatywy Demokratyczne" i publikowane systematycznie na stronach internetowych tych organizacji (www.razumkov.org.ua i www.dif.org.ua). Wszystkie te sondaże były oparte na próbach losowych reprezentatywnych dla dorosłych mieszkańców Ukrainy.

\footnotetext{
$3 \mathrm{~W}$ Polsce zinstytucjonalizowane badania opinii publicznej prowadzono również przed rokiem 1989. Pierwsze „prawdziwe” badanie sondażowe w Polsce zrealizował Stefan Nowak z zespołem w 1958 roku. Było to badanie studentów Warszawy (Sułek 1998). O związku między jakością danych sondażowych i stopniem akulturacji badań zob. Sułek 2001.
} 


\section{„TRUDNO POWIEDZIEĆ” A TEMATYKA PYTAŃ - WYNIKI ANALIZY DANYCH SONDAŻOWYCH}

Analiza porównawcza skłonności do udzielania odpowiedzi „trudno powiedzieć" na Ukrainie i w innych częściach Europy wskazuje, że częstszy niż gdzie indziej brak opinii Ukraińców dotyczy różnych zagadnień, choć najwyraźniej ujawnia się w odniesieniu do pytań o politykę. Mniej wyraźne jest to w przypadku poglądów na życie rodzinne, pracę itp. Co więcej, Ukraińcy zachowują się pod tym względem bardzo podobnie do obywateli Rosji, Białorusi i Mołdawii, czyli państw z którymi Ukrainę łączy wspólna historia.

W celu zbadania zależności między skłonnością do udzielania odpowiedzi „trudno powiedzieć” a tematyką sondażu porównano zestawy pytań dotyczących czterech zagadnień — dwóch „niepolitycznych” i dwóch politycznych. Były to pytania o ważność różnych spraw w życiu, o cechy udanego małżeństwa oraz ocena różnych systemów politycznych i postawy wobec systemu demokratycznego. Dane pochodzą z dwóch edycji międzynarodowego projektu badawczego European Values Survey ${ }^{4}$.

Oto zestawy pytań dotyczących znaczenia różnych wartości w życiu oraz życia rodzinnego:

Prosze powiedzieć, $w$ jakim stopniu uważa Pan/i/ następujące sprawy za ważne $w$ swoim życiu: praca, rodzina, przyjaciele i znajomi, czas wolny, polityka, religia.

O każdej z sześciu wartości respondent miał się wypowiedzieć osobno, możliwe było zatem udzielenie do sześciu odpowiedzi „trudno powiedzieć”

Oto lista cech, które zdaniem niektórych ludzi przyczyniaja się do udanego matżeństwa. O każdej $z$ nich prosze powiedzieć, czy Pana(i) zdaniem jest ona ważna czy tė̇ nieważna dla udanego matżeństwa.

Respondenci byli proszeni o wypowiedzenie się oddzielnie o każdej z dwunastu różnych cech: wierność, odpowiedni dochód, podobne pochodzenie społeczne, wspólne przekonania religijne, dobre warunki mieszkaniowe, zgoda w kwestiach politycznych, mieszkanie osobno od teściów, zadowolenie ze współżycia seksualnego, dzielenie obowiązków domowych, posiadanie dzieci, gotowość do rozmawiania o problemach, czas dla własnych przyjaciół i osobistych upodobań.

Zestawy pytań dotyczących kwestii politycznych brzmiały następująco:

Opiszę teraz różne typy systemów politycznych. Prosze powiedzieć, co Pan/i myśli o każdym z nich jako o sposobie rządzenia naszym krajem. Czy uważat(a) by go Pan/i za bardzo dobry, raczej dobry, raczej zły, czy bardzo zły sposób rzadzenia naszym krajem?

Respondenci byli proszeni o wypowiedź na temat następujących systemów politycznych: władza silnego przywódcy, władza ekspertów, rządy wojskowych,

${ }^{4}$ W czasie pisania tego artykułu dostępna była IV edycja EVS z lat 2008-2010. Na Ukrainie przeprowadzono ją w roku 2008 (www.europeanvaluesstudy.eu [01.02.2015]). 
demokratyczny system polityczny. O każdym z nich wypowiadali się osobno, możliwe więc było udzielenie od 0 do 4 odpowiedzi "trudno powiedzieć".

Drugi zestaw pytań „politycznych” dotyczył systemu demokratycznego i składał się również z czterech elementów, zatem również w tym przypadku możliwe było udzielenie od 0 do 4 odpowiedzi „trudno powiedzieć”.

Odczytam teraz kilka opinii, jakie ludzie czasami wypowiadaja na temat demokratycznego systemu politycznego. O każdej z nich prosze powiedzieć, czy zgadza się Pan/i/ $z$ nia, czy też nie?

Zadaniem respondentów było wyrażenie zgody lub sprzeciwu w stosunku do czterech stwierdzeń opisujących system demokratyczny: a) $w$ demokracji moga sie pojawić pewne problemy, ale jest ona lepsza niż inne formy rzadów; b) system gospodarczy funkcjonuje źle $w$ demokracji; c) $w$ demokracji brak jest zdecydowania $i$ zbyt wiele jest $w$ niej kłótni; d) ustrój demokratyczny nie radzi sobie $z$ utrzymaniem porzadku.

Dla każdego respondenta wyliczono udział procentowy odpowiedzi „trudno powiedzieć" wśród wszystkich odpowiedzi na każdy z przedstawionych zestawów pytań (wartości średnie tego wskaźnika zawiera tabela 1).

Tabela 1

Średni udział odpowiedzi „trudno powiedzieć” w grupie pytań dotyczących czterech zagadnień

\begin{tabular}{|l|c|c|c|c|r|r|r|r|}
\hline \multirow{2}{*}{$\begin{array}{l}\text { Obszar } \\
\text { pochodzenia }\end{array}$} & \multicolumn{2}{|c|}{$\begin{array}{c}\text { Wartości ważne } \\
\text { w życiu } \\
\text { respondentów* }\end{array}$} & \multicolumn{2}{|c|}{$\begin{array}{c}\text { Czynniki ważne } \\
\text { dla udanego } \\
\text { małżeństwa }\end{array}$} & $\begin{array}{c}\text { Opinie o różnych } \\
\text { systemach } \\
\text { politycznych }\end{array}$ & \multicolumn{2}{|c|}{$\begin{array}{c}\text { Opinie } \\
\text { o demokracji }\end{array}$} \\
\cline { 2 - 10 } & 1999 & 2008 & 1999 & 2008 & 1999 & 2008 & 1999 & 2008 \\
\hline Ukraina & $2,8 \%$ & $1,2 \%$ & $1,5 \%$ & $1,3 \%$ & $23,0 \%$ & $18,0 \%$ & $20,8 \%$ & $17,0 \%$ \\
Europa Środkowa & $0,5 \%$ & $0,3 \%$ & $1,1 \%$ & $1,1 \%$ & $7,8 \%$ & $8,0 \%$ & $9,8 \%$ & $10,3 \%$ \\
Europa Zachodnia & $0,3 \%$ & $0,2 \%$ & $0,9 \%$ & $1,0 \%$ & $7,5 \%$ & $6,3 \%$ & $10,5 \%$ & $8,5 \%$ \\
\hline
\end{tabular}

* Kategoria „Europa Środkowa” to Polska, Czechy, Węgry i Słowacja, kategoria „Europa Zachodnia" to Austria, Belgia, Francja, Irlandia, Luksemburg, Niemcy i Wielka Brytania.

Źródło: European Values Survey, obliczenia własne.

Jak widać, Ukraińcy częściej uchylają się od odpowiedzi niż społeczeństwa krajów środkowoeuropejskich i zachodnich, a dotyczy to nie tylko zagadnień politycznych. Widać również, że na wszystkich badanych obszarach geograficznych występowała zaobserwowana kiedyś przez Bourdieu i analizowana także przez innych badaczy (zob. np. Laurison 2007) różnica między odsetkami odpowiedzi „nie wiem” na pytania polityczne i niepolityczne. Różnica ta pojawiła się w obu punktach czasowych i na Ukrainie była znacznie większa niż u jej zachodnich sąsiadów.

Szczególnie wyraźnie rysuje się to z perspektywy wskaźnika skonstruowanego nieco inaczej niż ten $z$ tabeli 1 , a mianowicie odsetka osób, które częściej odpowiadają „trudno powiedzieć”, gdy są pytane o politykę niż gdy pytanie 
dotyczy innych kwestii (zob. wykres 1) ${ }^{5}$. W tym przypadku „inne kwestie” były reprezentowane przez pytanie dotyczące tego, $w$ jakim stopniu ważne są $\mathrm{w}$ życiu wymienione $\mathrm{w}$ ankiecie cytowane już wartości ${ }^{6}$.

Wykres 1

Odsetek osób, które częściej uchylają się od odpowiedzi na pytania o systemy polityczne niż na pytania o różne wartości w życiu

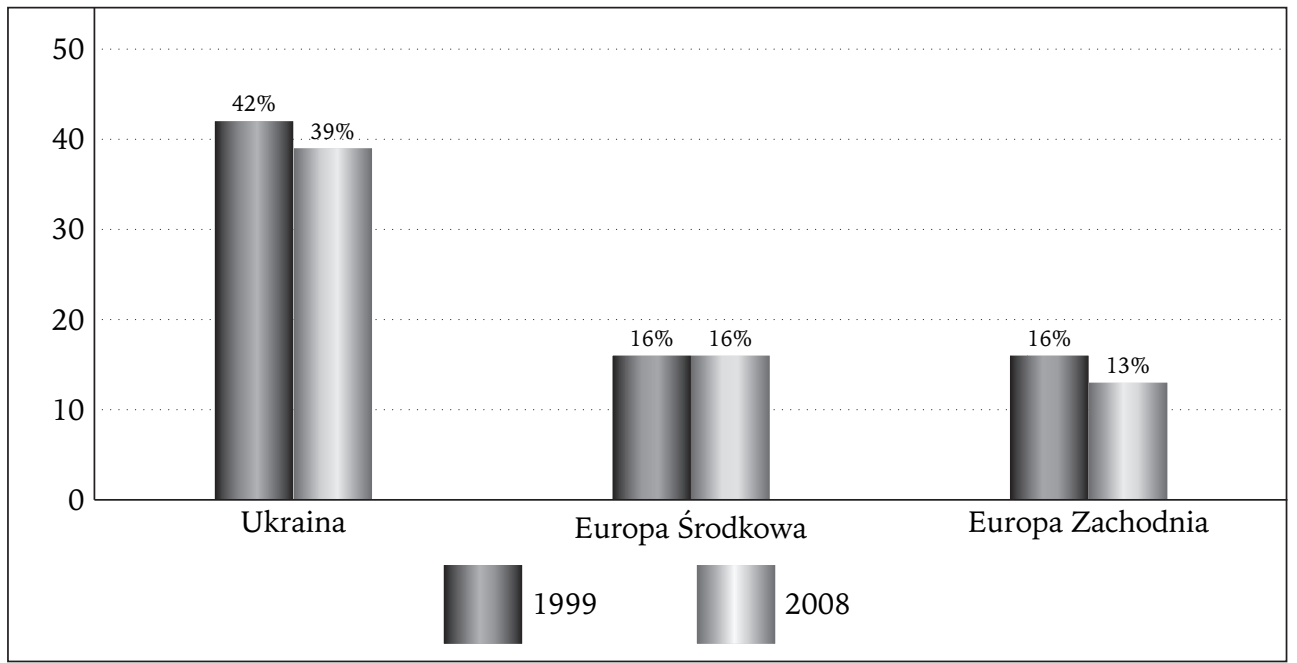

Źródło: European Values Survey, obliczenia własne.

Stabilne w czasie pozostają zarówno różnice między Ukrainą a Europą Środkową i Zachodnią, jak i te między liczbą odpowiedzi „trudno powiedzieć” na pytania o zagadnienia polityczne i niepolityczne. Dzieje się tak, mimo że w okresie dzielącym oba badania na Ukrainie miała miejsce Pomarańczowa Rewolucja, która zaangażowała wiele osób i z którą wielu Ukraińców wiązało nadzieje na społeczne i polityczne zmiany w kraju. Przytoczone dane sugerują, że wydarzenia te nie doprowadziły do poszerzenia społecznej bazy osób chętnych do zajmowania stanowiska w kwestiach dotyczących polityki, a więc prawdopodobnie również gotowych do działania politycznego.

Badanie czynników sprzyjających udzielaniu odpowiedzi „trudno powiedzieć" na pytania dotyczące tego, który system polityczny byłby najbardziej

5 Dla klarowności wykres i dalsze analizy tego wskaźnika ograniczają się do porównania dwóch zestawów pytań - o najlepszy ustrój polityczny oraz o ważność różnych wartości w życiu. Analizy przeprowadzone na podstawie pozostałych pytań $z$ tabeli 1 prowadzą do identycznych wniosków.

${ }^{6}$ Porównywane były udziały pytań z odpowiedziami „trudno powiedzieć”. Jeśli ktoś udzielił takiej odpowiedzi na jedno z czterech pytań „politycznych”, to udział wynosił 0,25, jeśli na dwa to udział był 0,5 itd. Pytań o wartości było sześć, więc odpowiedź „trudno powiedzieć” na jedno $z$ nich, to udział 0,17 , na dwa - 0,33 itd. 
odpowiedni dla Ukrainy (pierwszy z omawianych „zestawów politycznych”), wykazało, że tylko cztery czynniki są istotne: płeć (kobiety częściej nie miały zdania niż mężczyźni), fakt korzystania z pomocy społecznej w ciągu pięciu lat poprzedzających badanie (korzystający z pomocy częściej nie mieli zdania), posiadanie wyższego wykształcenia oraz status społeczno-zawodowy ${ }^{7}$. W użytym do analizy modelu ${ }^{8}$ uwzględniono też inne zmienne: dochód, wielkość miejscowości oraz region zamieszkania i język wywiadu, jednak ich wpływ okazał się statystycznie nieistotny.

W pewnym sensie otrzymany wzór zależności był podobny do tego, który opisał Bourdieu, choć wpływ wysokości dochodów w uzyskanym modelu okazał się tak niewielki, że nie przechodził testów istotności statystycznej. Osoby o wyższej pozycji społecznej miały jednak — jak u Bourdieu — mniejszą skłonność do uchylania się od odpowiedzi na pytania polityczne niż osoby o pozycji niższej. W odniesieniu do Ukrainy trudno jednak wyciągnąć z tego wniosek, $\dot{z}$ e oto pokazaliśmy mechanizm opisany przez Bourdieu, polegający na tym, że część obywateli sama zawiesza swoją rolę obywateli i wycofuje się z wpływu na państwo i jego politykę, przyczyniając się tym samym do utrwalenia istniejącej struktury społecznej.

Rzecz w tym, że na Ukrainie status społeczno-zawodowy nie był stawką $\mathrm{w}$ grze (to nie wykształcenie czy rodzaj uprawianego zawodu były czynnikiem, od którego zależało miejsce $\mathrm{w}$ strukturze pozwalające wpływać na politykę), a osoby wpływające na politykę państwa nie czyniły tego stosując znane $z$ państw demokratycznych mechanizmy działania politycznego, lecz wykorzystywały powiązania typu klientelistycznego, które w niewielkim stopniu zależały od statusu społeczno-zawodowego. Przynajmniej tak było w czasie, w którym prowadzono analizowany sondaż - czas pokaże, czy rewolucja $z$ lat 2013-2014 przyniesie w tej dziedzinie jakąś znaczącą zmianę.

$\mathrm{W}$ rezultacie nawet $\mathrm{w}$ grupach o najwyższym statusie społeczno-zawodowym odsetek osób odpowiadających „trudno powiedzieć” był w 2008 roku bardzo wysoki (blisko 27\%), problematyczne byłoby więc twierdzenie, że tego rodzaju wycofywanie się z polityki jest domeną ludzi o niskim statusie, a ci o wyższym w pełni uczestniczą w dyskursie politycznym. Ponadto - i to może nawet ważniejsze - nie stwierdzono żadnej korelacji między skłonnością do uchylania się od odpowiedzi na analizowane pytania a deklarowaną chęcią głosowania w wyborach. Brak zdania w kwestiach pożądanego ustroju politycznego nie wpływał na chęć udziału w głosowaniu.

\footnotetext{
$7 \mathrm{~W}$ badaniu EVS był on mierzony za pomocą międzynarodowej klasyfikacji EGP (więcej o tej klasyfikacji: Domański 2012, s. 27).

8 Zastosowano model regresji logistycznej, w którym zmienną zależną była zmienna zdająca sprawę z tego, czy respondent częściej odpowiadał „trudno powiedzieć” na pytania o politykę niż na inne.
} 
Wydaje się, że czynnikami najsilniej oddziałującymi na odsetek uchylających się od odpowiedzi, nie uwzględnionymi w sondażu, są: (1) przekonanie o tym, czy myślenie o polityce ma w ogóle jakiś sens i do czegokolwiek prowadzi oraz (2) zaufanie do badacza (ankietera). Ukraińcy w roku 2008 byli bardzo sfrustrowani rozwojem sytuacji w kraju - na skali zadowolenia $z$ demokracji uzyskali jeden z najniższych wyników wśród objętych badaniem krajów (niżej swą demokrację ocenili tylko Albańczycy). Dodatkowo poziom zaufania do badań społecznych obniżały pojawiające się przy okazji kolejnych sondaży przedwyborczych oskarżenia o „fałszowanie badań”. W rezultacie pytanie o to, jaki ustrój byłby dla Ukrainy najbardziej pożądany, wielu respondentów najprawdopodobniej odebrało jako drażliwe - dotyczące ich prywatnych poglądów, którymi nie życzyli sobie dzielić się z przychodzącym ze świata oficjalnego ankieterem.

Pytanie obywateli o pożądany system polityczny ma sens $\mathrm{w}$ państwie demokratycznym, w którym obywatele mają — przynajmniej w teorii - realny wpływ na to, kto rządzi i jak rządzi. Konstytucja Ukrainy w art. 1 definiuje państwo jako „demokratyczne, socjalne państwo prawa”, a w art. 5 jako suwerena i źródło władzy wskazuje „naród”. Paradoks polega jednak na tym, że sam „naród” nie tylko nie do końca godzi się z określeniem swej ojczyzny jako „demokratycznej”, ale w dodatku około $1 / 3$ obywateli nie potrafi lub nie chce zająć w tej kwestii stanowiska. Co więcej, odsetek uchylających się od jego zajęcia utrzymuje się na stałym poziomie i nie zmniejszyły go nawet wydarzenia z przełomu roku 2013 i 2014, choć spowodowały one, że Ukraina jest dziś częściej uważana za demokratyczną niż za niedemokratyczną.

Kolejnym pytaniem, na które odpowiadając duża część respondentów korzysta z możliwości „trudno powiedzieć”, jest miejsce Ukrainy na geopolitycznej mapie Europy. Również w tym przypadku można zauważyć dość dużą stabilność grupy osób uchylających się od odpowiedzi. W ciągu dziesięciu lat około jednej piątej badanych stale miało kłopot $z$ odpowiedzią na pytanie o to, czy Ukraina powinna wstąicić do Unii Europejskiej, czy też nie. Fluktuacja odsetków odpowiedzi „trudno powiedzieć” okazała się relatywnie niewielka w porównaniu do ich zróżnicowania w przypadku odpowiedzi „tak” i „nie” 9 , co ilustruje wykres 3.

Pytanie o przystąpienie do Unii Europejskiej najprawdopodobniej jest dla respondentów trudne, przede wszystkim z powodu abstrakcyjności. Osoby zorientowane $\mathrm{w}$ sprawach politycznych rozumieją, że nie jest to realna opcja, a pytanie ma charakter hipotetyczny. Ci, którzy nie znają się na polityce zagranicznej, mieli przez lata niewiele łatwo dostępnych źródeł pozwalających uzupełnić wiedzę w tym zakresie. Bardzo niewielu Ukraińców kiedykolwiek było w Unii Europejskiej (Fomina i in. 2013), a media poświęcały szeroko po-

9 Odchylenie standardowe odsetków odpowiedzi „trudno powiedzieć” to 2,6, podczas gdy dla odsetka odpowiedzi „tak” wynosi 5,7, a dla „nie” blisko 6 . 
Czy Ukraina jest państwem demokratycznym? (dynamika 2009-2014) (w \%)

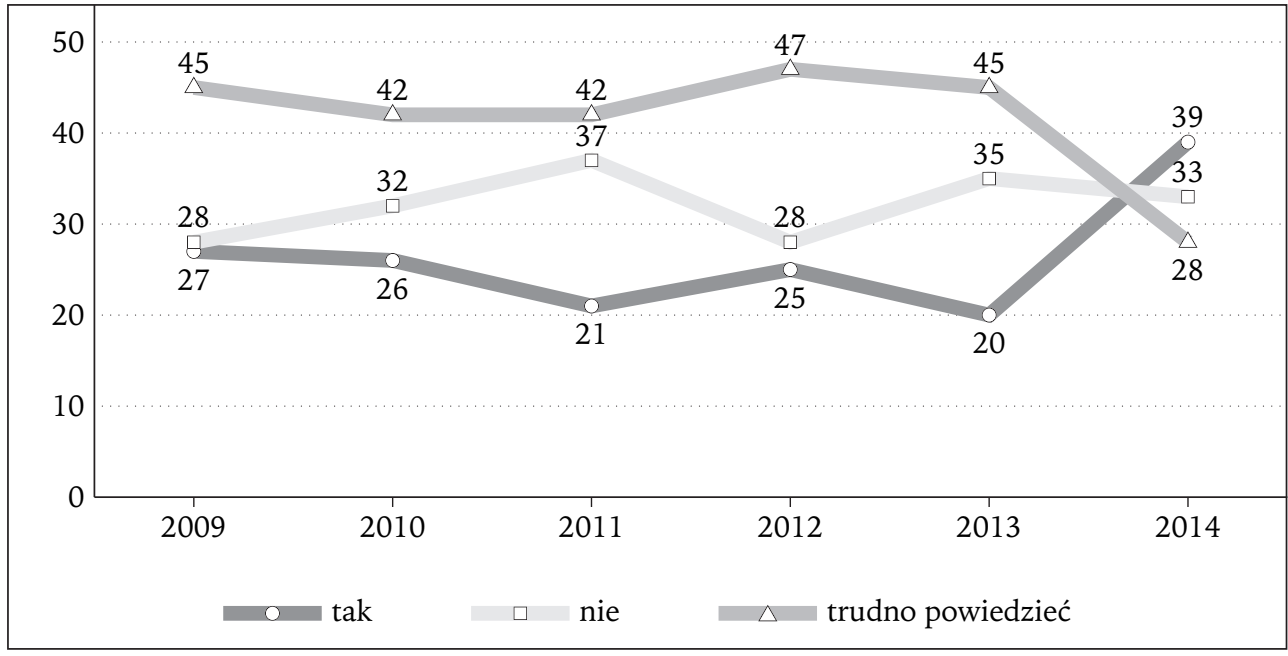

Źródło: International Foundation for Electoral Systems (http://www.ifes.org).

Wykres 3

Czy Ukraina powinna wstąpić do Unii Europejskiej? (2002-2012) (w \%)

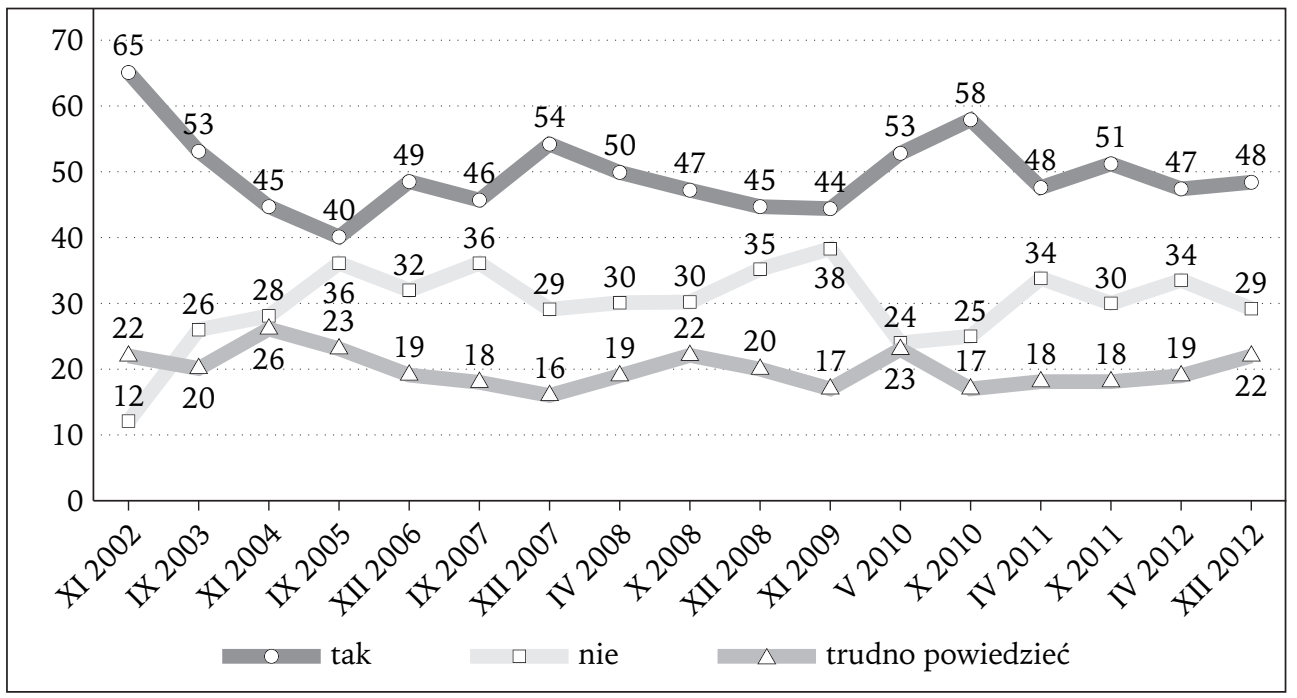

Źródło: Centrum Razumkowa (www.razumkov.org.ua).

jętemu Zachodowi bardzo niewiele uwagi (Kułyk 2010). Sytuacja w mediach zmieniła się właściwie dopiero w okresie przygotowań do Euro 2012 i do pla- 
nowanego na listopad 2013 roku podpisania umowy stowarzyszeniowej z Unią Europejską.

Jak wskazuje wykres 4, Ukraińcom łatwiej było odpowiedzieć na pytanie o pożądany priorytet polityki zagranicznej niż o przystąpienie do Unii Europejskiej. Pytanie to sformułowano w sposób bardziej realistyczny: w końcu każdy kraj prowadzi politykę zagraniczną i respondenci nie musieli sobie wyobrażać czysto hipotetycznej sytuacji. Odsetek odpowiedzi „trudno powiedzieć" okazał się tym razem niemal dwukrotnie mniejszy niż w pytaniu o Unię i ulegał bardzo niewielkim wahaniom w czasie. Od 2010 roku obserwujemy jednak systematyczny wzrost udziału odpowiedzi „trudno powiedzieć”, któremu towarzyszy częstsze wybieranie opcji zachodniej (stosunki z Unią Europejską jako priorytetowe) niż wschodniej (stosunki z Rosja).

Wykres 4

Jaki kierunek polityki zagranicznej powinien być priorytetowy dla Ukrainy? (w \%)

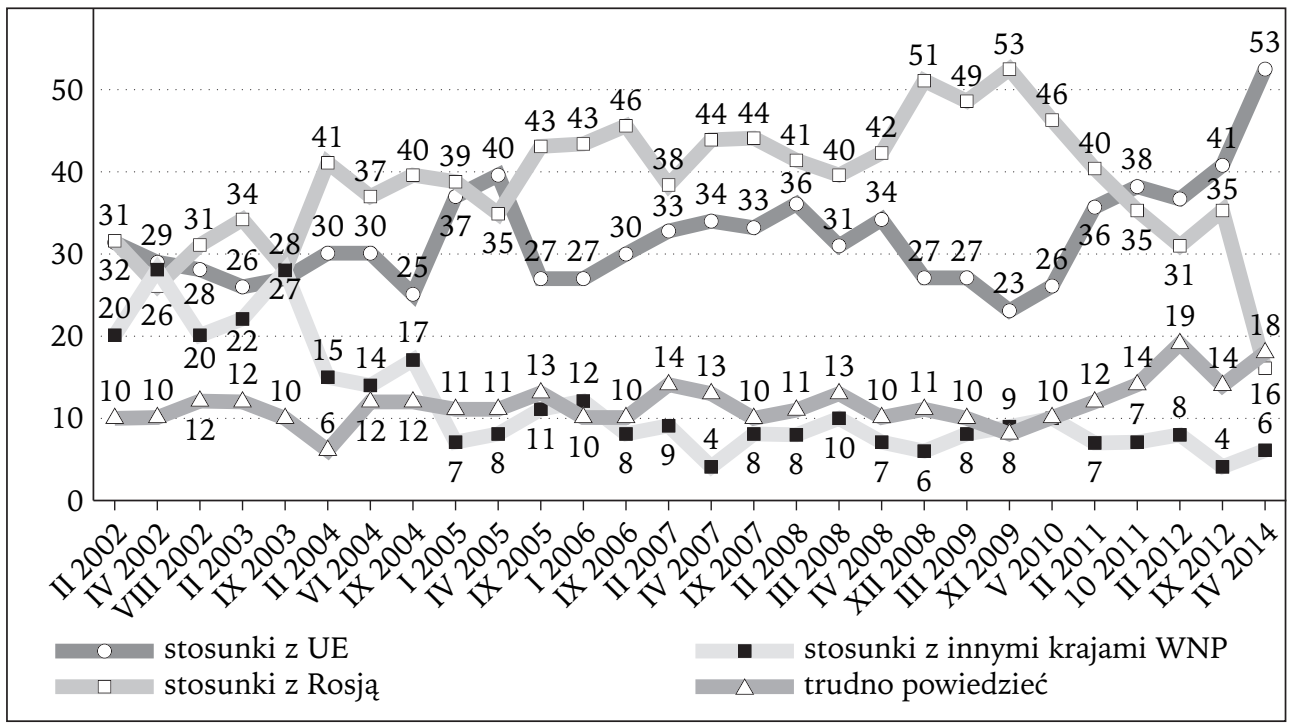

Na wykresie pominięto opcje „stosunki z USA” i „stosunki z innymi krajami”.

Źródło: Centrum Razumkowa (www.razumkov.org.ua).

Analiza korelacji przedstawionych na wykresie szeregów czasowych sugeruje, że ucieczka w „trudno powiedzieć” $\mathrm{w}$ pewnym stopniu, choć nie całkowicie, zastępowała wybór opcji rosyjskiej (korelacja między tymi odsetkami była negatywna, a współczynnik wynosił $r=-0,51)$. W ostatnim sondażu z 2014 roku „trudno powiedzieć” najczęściej odpowiadali badani z regionów wschodniego (22\%) i południowego (23\%), a więc tam, gdzie zazwyczaj notowano większą skłonność do patrzenia na wschód. 
Widać także - co warto podkreślić na marginesie — że te zmiany rozkładu opinii respondentów w badanej kwestii i stopniowy wzrost odsetka „trudno powiedzieć" rozpoczęły się na kilka lat przed zaostrzeniem się stosunków ukraińsko-rosyjskich w związku z wydarzeniami na Majdanie.

Hipotezę o zastępowaniu opcji prorosyjskiej przez „trudno powiedzieć" w sposób bardziej bezpośredni potwierdzają jeszcze inne wyniki sondaży Centrum Razumkowa. W grudniu 2013 roku ośrodek ten zadał swoim respondentom inaczej sformułowane pytanie o priorytety polityki zagranicznej Ukrainy. Zapytano, do której ze wspólnot międzynarodowych Ukraina powinna przystąpić - do Unii Europejskiej czy do unii celnej z Rosją, Białorusią i Kazachstanem. Sondaż powtórzono po roku, w grudniu 2014 roku. Okazało się, że w ciągu tego roku nastąpiły dwie zmiany w rozkładach opinii: wyraźnie spadł odsetek zwolenników unii celnej z Rosją (z 36\% do 16\%) i jednocześnie niemal równie spektakularnie zwiększył się odsetek osób, które nie miały w badanej sprawie zdania: w 2013 roku takie osoby stanowiły 18\%, a w 2014 już 27\% badanych, czyli więcej niż jedną czwartą ${ }^{10}$. Odsetek zwolenników Unii Europejskiej wzrósł w tym czasie z $46 \%$ do $57 \%$.

Ta sytuacja może wydawać się paradoksalna, gdyż Euromajdan i następujące po nim wydarzenia polityczne zaangażowały bardzo znaczne rzesze społeczne i wydaje się, że powinno to zaowocować zmniejszaniem się, a nie wzrostem udziału osób uchylających się od zajęcia stanowiska politycznego. Warto jednak wrócić do przedstawionych na początku przyczyn unikania merytorycznych odpowiedzi na pytania i uciekania w „trudno powiedzieć”. Cytowane badania Lutyńskiej wykazały, że dzieje się to najczęściej w dwóch przypadkach — gdy pytanie jest trudne i respondentowi „nie chce się" nad nim zastanawiać oraz gdy pytanie jest drażliwe. Lutyńska stwierdziła także, że oddziaływanie drażliwości jest silniejsze, to znaczy że ten czynnik częściej skłania do uchylenia się od odpowiedzi niż trudność pytania.

Pytanie o to, który kierunek polityki zagranicznej powinien być dla Ukrainy priorytetowy, dla niektórych respondentów mogło być trudne i głównie $z$ tego powodu odpowiadali „trudno powiedzieć”. W sytuacji zwiększonej presji Rosji na Ukrainę - z początku propagandowej, wreszcie wojskowej - kwestia stosunku do Rosji stała się drażliwa. W mediach społecznościowych i „tradycyjnych" można natknąć się na wiele opowieści o utracie znajomych czy nawet przyjaciół z powodu różnic $\mathrm{w}$ interpretacji stosunków ukraińsko-rosyjskich. Gdy w takich warunkach przychodzi do domu ankieter i pyta o stanowisko w sprawie unii celnej z Rosją, niechęć do udzielenia prawdziwej odpowiedzi jest zrozumiała. Respondent nie wie, co na ten temat myśli ankieter i nie chce,

$10 \mathrm{~W}$ drugim z badań nie wzięli udziału mieszkańcy zaanektowanego przez Rosję Krymu, którzy zazwyczaj charakteryzowali się bardziej prorosyjskimi poglądami niż reszta mieszkańców Ukrainy. Jednak opisywane zmiany rozkładu opinii nie mogą wynikać jedynie z wyłączenia Krymu z sondażu. Na półwyspie mieszka zaledwie ok. 4\% mieszkańców Ukrainy. 
by okazało się, że są po przeciwnych stronach barykady. Drażliwość pytania częściej niż jego trudność skłania do ucieczki w „trudno powiedzieć” — stąd wzrost odsetka tych odpowiedzi.

Ukraińcy lubią odpowiadać „nie wiem” i wydaje się, że dość często jest to swojego rodzaju skrócona wersja „nie wiem, co powinienem odpowiedzieć” lub „nie wiem, co warto odpowiedzieć”. Tak było w przypadku pytań o politykę zagraniczną Ukrainy, gdy trudność pytania związana z jego abstrakcyjnością i z tym, że odpowiedź wymaga od respondenta przynajmniej ogólnej orientacji $\mathrm{w}$ świecie polityki, straciła na znaczeniu $\mathrm{w}$ porównaniu $\mathrm{z}$ jego drażliwością. Agresja Rosji wobec Ukrainy w zestawieniu z silnymi związkami kulturalnymi i osobistymi przez lata łączącymi społeczeństwa tych krajów spowodowała, że pytania, w których dotyka się zagadnienia relacji ukraińsko-rosyjskich, stały się drażliwe.

W przypadku pytań dotyczących polityki wewnętrznej „trudno powiedzieć” znaczy z kolei najprawdopodobniej rzeczywiście brak opinii w danej sprawie, co związane jest z tym, że Ukraińcy nie uważają jej za wartą rozważania. Jeszcze do niedawna „opinia społeczna” nie była siłą polityczną i miała na Ukrainie niewielkie znaczenie, gdyż politycy i działacze partyjni nie uważali za stosowne się z nią liczyć. Wydarzenia z przełomu lat 2013 i 2014 pokazały siłę „opinii społecznej”, co zapewne z czasem przełoży się na skłonność Ukraińców do zajmowania stanowiska $\mathrm{w}$ kwestiach politycznych również $\mathrm{w}$ sondażach opinii publicznej. Do tego jednak potrzebne jest także zaufanie do samych badań i instytucji, które je realizują.

\section{BIBLIOGRAFIA}

Bishop George F., Tuchfarber Alfred J., Oldendick Robert W., 1996, Opinions on Fictitious Issues: The Pressure to Answer Survey Questions, „The Public Opinion Quarterly”, t. 50, s. 240-250.

Bourdieu Pierre, 2006 [1979], Dystynkcja. Społeczna krytyka władzy sądzenia, tłum. Piotr Biłos, Scholar, Warszawa.

Chmelko W. E, 2014, Dinamika poddzierżki nasielieniem suwierieniteta Ukrainy w pierwyje diesiatiletija jejo gosudarstwiennoj niezawisimosti (1991-2014 gody) (strony internetowe Kijowskiego Międzynarodowego Instytutu Socjologii: http://www.kiis.com.ua/materials/articles_HVE/Support_of State_Sovereignty_in_Ukraine.pdf [25.02.2015]).

Chudowsky Victor, Kuzio Taras, 2003, Does Public Opinion Matter in Ukraine? The Case of Foreign Policy, „Communist and Post-Communist Studies”, t. 36(3), s. 273-290.

Domański Henryk, 2012, Metodologia badań nad struktura spoteczna, Scholar, Warszawa.

Fomina Joanna i in., 2013, Polska-Ukraina. Polacy-Ukraińcy. Spojrzenie przez granice, Fundacja Instytut Spraw Publicznych, Warszawa.

Gęsicka Grażyna, Kolarska-Bobińska Lena, Wertenstein-Żuławski Jerzy (red.), 1987, Badania ankietowe we wspótczesnym spoteczeństwie polskim, Polskie Towarzystwo Socjologiczne, Warszawa. 
Konieczna-Sałamatin Joanna, 2011, Ukraina - ucieczka od wyboru, „Nowa Europa Wschodnia”, nr 3-4.

Kułyk Wołodymyr, 2010, Dyskurs ukrajinśkych medij: identycznosti, ideotohiji, władni stosunky, Krytyka, Kyjiw.

Laurison Daniel, 2007, Refusing to Engage: Political Competence and the 'Don't Know' Response on Surveys. Symposium: Democracy and Its Development 2005-2011, Center for the Study of Democracy, Univerisity of California, Irvine (https://escholarship.org/uc/item/2xk9z1rx).

Lutyńska Krystryna, 1990, Odpowiedzi typu „trudno powiedzieć” $w$ latach osiemdziesiatych $w$ Polsce $i$ ich uwarunkowanie, w: Analizy i próby technik badawczych $w$ socjologii, t. 8, Zygmnut Gostkowski (red.), Ossolineum, Wrocław.

Mansurow W. A., Pietrienko E. S., 1996, Izuczenije obszczestwiennogo mnienija $w$ Rossii $i$ SSSR, w: W. A. Jadow (red.), Sociotogija w Rossii, Izdatielstwo „Na Worobjewych”, Moskwa (http://ecsocman.hse.ru/data/971/698/1219/022Glava19.pdf [25.02.2015]).

Riabchuk Mykola, 1998, Civil Society and Nation Building in Ukraine, w: Taras Kuzio (red.), Contemporary Ukraine: Dynamics of Post-Soviet Transformation, M.E. Sharpe, Armonk.

Rostocki Włodzimierz, 1974, Pytania drażliwe w wywiadzie socjologicznym, w: Zygmunt Gostkowski (red.), $Z$ metodologii i metodyki socjologicznych badań terenowych, IFiS PAN, Warszawa.

Sułek Antoni, 1998, Jak Stefan Nowak studentów sondowat, „Gazeta Wyborcza”, 2 czerwca.

Sułek Antoni, 2001, Demokratyczna zmiana ustroju a rzetelność badań sondażowych. Doświadczenie polskie, w: Antoni Sułek, Sondaż polski, Wydawnictwo IFiS PAN, Warszawa.

Śmiłowski Eugeniusz, 1987, „Trudno powiedzieć” jako wyraz niepewności respondenta, „Biuletyn CBOS”, nr 4.

Wilson Andrew, 2002, Ukraińcy, tłum. Marek Urbański, Fakty-Bertelsman Media, Warszawa.

\section{THE 'HARD-TO-SAY' PARTY IN UKRAINE: WHAT REFRAINING FROM ANSWERING SURVEY QUESTIONS SAYS ABOUT UKRAINIAN SOCIETY}

\section{Sum mary}

The aim of this analysis was to determine why, in public opinion surveys in Ukraine, a decidedly larger proportion of respondents than in countries of western and central Europe do not have their own opinion. The author believes that the causes are primarily two popular attitudes in the Ukraine: (1) the conviction that it doesn't make sense for an 'ordinary person' to think about public affairs, because he has no chance to effect any sort of change; and (2) lack of trust in the survey-taker and the associated sense of the situation as being a sensitive one. The author's inquiries reveal a higher degree of political alienation in Ukraine than in the majority of EU countries, and a lower level of civic engagement. At the same time, the author expresses the view that the revolution of $2013 / 2014$ probably testifies to the fact that in the last few years the sense of detachment has decreased and will continue to diminish.

\section{Key words/słowa kluczowe}

public opinion research / badania opinii publicznej; European Values Survey; doublethink / dwójmyślenie; civic engagement in Ukraine / zaangażowanie obywatelskie na Ukrainie 